\title{
Evaluation of Drying Kinetics and Activation Energy of Oyster Mushroom (Pleurotus ostreatus)
}

\author{
1*Ajala, A.S., ${ }^{2}$ Ogunsola A.D. and ${ }^{3}$ Akanbi, T.A. \\ ${ }^{1}$ Department of Food Engineering, Ladoke Akintola University of Technology, P.M.B. 4000, Ogbomoso, Oyo State, \\ Nigeria \\ ${ }^{2}$ Department of Mechanical Engineering, Ladoke Akintola University of Technology, P.M.B. 4000, Ogbomoso, Oyo \\ State, Nigeria \\ ${ }^{3}$ Agricultural and Rural Management Training Institute, Ilorin, Kwara State, Nigeria \\ *Corresponding Author E-mail: asajala@lautech.edu.ng; ajlad2000@yahoo.com
}

Submitted on: 01/02/2021

Accepted on: $22 / 03 / 2021$

\begin{abstract}
Oyster mushroom (Pleurotus ostreatus) is a fungus which easily deteriorates after harvest and hence, there is need to make it stable by reducing its moisture content to a lower level after harvest. In this study, fresh oyster mushrooms were dried using three modes of drying: sun at an average temperature of $32^{\circ} \mathrm{C}$, solar at an average temperature of $40^{\circ} \mathrm{C}$ and tunnel dryer at $50^{\circ} \mathrm{C}$. Kinetics of moisture drying was modelled using Fick's second law of diffusion which is generally applicable to thin-layer drying of agricultural products. Six models namely Henderson and Pabis, Logarithms, Newton, Page, Two Terms and Midilli Kucuk were employed for the drying kinetics. Nonlinear regression analysis was carried out using Statistical Package for Social Scientist (SPSS 16.0 version) to fit the experimental data. The reliability of the models was tested using some statistical criteria such as coefficient of determination $\left(R^{2}\right)$, reduced chi-square $\left(\chi^{2}\right)$, Mean Bias Error (MBE) and Root Mean Square Error (RMSE). The model which had the best fit was chosen to represent the drying behaviour of oyster mushroom. The drying pattern was observed to be in the single falling rate period in the entire drying modes. The values of $R^{2}$ ranged from $0.0 .933-0.988, \chi^{2}(2.4 E-06-$ 0.044), MBE (-7.6E-4-0.044) and RMSE (7.8E-4-0.201). Effective moisture diffusivity for samples dried in the sun, solar and tunnel were $1.19 \mathrm{E}-11 \mathrm{~m}^{2} / \mathrm{s}, 1.21 \mathrm{E}-11 \mathrm{~m}^{2} / \mathrm{s}$ and $1.59 \mathrm{E}-11 \mathrm{~m}^{2} / \mathrm{s}$, respectively. Two Term model best described drying behavior of oyster mushroom during tunnel drying and the activation energy of the model was $64.9 \mathrm{~kJ} / \mathrm{mol}$.
\end{abstract}

Keywords: Oyster mushroom, drying, models, effective diffusivity, activation energy.

\section{Introduction}

Pleurotus species otherwise known as oyster mushrooms are fungi with distinct fleshy fruiting bodies. It is often found on dead trees as a primary degrader of wood and vegetable residues (Zadrazil and Kurtzman, 1981). It has the ability to colonise and degrade a large variety of lignocellulosic residues, shorter growth time when compared to other edible mushrooms (Giannini et al.,2010). It has been reported to have got an excellent flavour and taste when cooked to form delicacies (Jonathan and Esho, 2010). Mushroom production has increased globally by 10 times in the past four decades (Zhang et al., 2014) and a gradual increase in world mushroom production had been observed from 2000-2007. For instance, in 2000, mushroom production was 26 million tons and it rose to 33.4 million tons in 2007 (Celik and Pekers 2009, Gebresadkan 2015) and this has made mushroom farmers usually make millions of dollars from this single species (Jonathan et al., 2012). Oyster mushroom is reported to have high quantities of proteins, carbohydrates, minerals (calcium, phosphorus, iron) vitamins (thiamin, riboflavin and niacin) as well as low fat (Manzi et al., 1999; Kurtzman, 2005). Several authors have reported the usefulness of oyster mushroom in 
research, for instance, Ajala and Taiwo (2018) studied oyster mushroom in fortification of 'ogi', Caglarirmak, (2007) examined the nutrients of oyster mushroom and estimated approach to its volatile compounds, Eswaran and Ramabradan (2000) studied some physicological, cultural, and post-harvest aspects of oyster mushroom.

However, despite its tendency to be abundantly available, oyster mushroom has been grossly scarce in Nigeria's market due to its very short shelf life. This is because it is more delicate and sensitive. It starts deteriorating immediately within one day after the harvest. Once deteriorated, these fruiting bodies can cause severe gastrointestinal discomfort (Lukasse and Polderdijk, 2003). Under freezing climatic conditions, the shelf life of these mushrooms is about 10 days, their quality being affected predominantly by storage temperature. The shelf life can be reduced from 9 days at $2{ }^{\circ} \mathrm{C}$ to 3 days at $18^{\circ} \mathrm{C}$ (Lukasse and Polderdijk, 2003). Another reason for its short shelf life is because it is highly perishable due to its high moisture content of 87-95\% (Sergey et al., 2020) and according to Maray et al. (2017), it cannot be stored for more than $24 \mathrm{~h}$ in the ambient temperature of $28{ }^{\circ} \mathrm{C}$ environment and 5-7 days after cooling. Consequently, it is not commonly available in the market for consumers. Therefore it is necessary to transform it to a more stable form by drying. To effectively dry this material, there is a need to model its drying characteristics in order to know the activation energy that would be involved in the drying process. This is the objective of the paper.

\section{Materials and Methods}

\section{(a) Drying Experiment}

$2 \mathrm{~kg}$ weights of fresh and clean oyster mushrooms were obtained from the National Development Biotechnology Agency (NADBA), Ogbomoso, Oyo State, Nigeria. They were sorted to eliminate all forms of dirt and physical contaminants that were likely to be present in the samples. After that, the sorted mushrooms were dried. The drying experiment was performed using the sun (average temperature of $32^{\circ} \mathrm{C}$ ), cabinet solar (average temperature of $40^{\circ} \mathrm{C}$ ) and tunnel dryer $\left(50^{\circ} \mathrm{C}\right)$. The cabinet solar and tunnel dryer were built in the Department of Food Engineering, Ladoke Akintola University of Technology, Ogbomoso Nigeria. Mushrooms were cut into a rectangular slab-like structure for the experiments. The mushrooms had average dimensions of $3 \times 1 \times 0.15 \mathrm{~cm}$ for length, breadth and thickness measured with Veneer calliper. The samples were weighed manually every 1 hour to determine the weight loss of the sample. The drying experiment was stopped when three consecutive sample weights remained constant (Goyal et al., 2007).

\section{(b) Mathematical model}

To understand the suitable model for the drying characteristics of the samples, the experimental data were fitted in six models described in Table 1.

These models show relationship between moisture ratio and drying time. Moisture ratio (MR) during the thin layer drying was obtained using Equation 1

$\mathrm{MR}=\frac{M_{i}-M_{e}}{M_{O}-M_{e}}$ 
LAUTECH Journal of Civil and Environmental Studies

Volume 6, Issue 1; March 2021

Table 1. Mathematical drying models

\begin{tabular}{lll}
\hline Models & Equation & References \\
\hline Henderson and Pabis & $M R=a_{1} \exp \left(-k_{1} t\right)$ & Hii et al, (2009) \\
Logarithms & $M R=a_{2} \exp \left(-k_{2} t\right)+c_{2}$ & Togrul and Pehlivan, (2003) \\
Newton & $M R=\exp \left(-k_{3} t\right)$ & Kingly et al., (2007) \\
Page & $M R=\exp \left(-k_{4} t^{n}\right)$ & Karathanos and Belessiotis, \\
& $M R=a_{5} \exp \left(-k_{5} t\right)+b_{5} \exp (j t)$ & Hodge \& Taylor, (1999) \\
Two term & $M R=a_{6} \exp \left(-k_{6} t^{n}\right)+b_{6} t \quad$ Midilli et al., (2002) \\
Midilli-Kucuk & &
\end{tabular}

Where $\mathrm{MR}=$ dimensionless moisture ratio, $\mathrm{Mi}=$ instantaneous moisture content ( $\mathrm{g}$ water/g solid), $\mathrm{Me}=$ equilibrium moisture content ( $\mathrm{g}$ water/ $\mathrm{g}$ solid), $\mathrm{Mo}=$ initial moisture content ( $\mathrm{g}$ water/ $\mathrm{g}$ solid). However, due to continuous fluctuation of relative humidity of the drying air in the dryer, Equation 1 is simplified in Equation 2 according to Goyal et al., (2007)

$\mathrm{MR}=\frac{M_{i}}{M_{O}}$

\section{(c) Determination of Moisture Diffusivity}

Fick's equation was simplified to describe the drying characteristics of banana peel samples. The simplified equation was used to determine the effective moisture diffusion from the samples during drying. The equation according to Ajala et al. (2012b) is represented thus:

$\mathrm{MR}=\frac{M-M_{0}}{M_{0}-M_{e}}=\frac{8}{\pi^{2}} \sum_{n=0}^{n=1} \frac{1}{(2 n-1)^{2}} \exp \frac{-(2 n-1)^{2} \pi^{2} D_{e f f} t}{4 l^{2}}$

Where $D_{\text {eff }}$ is the moisture diffusivity $\left(\mathrm{m}^{2} / \mathrm{s}\right), t$ is the drying time $(\mathrm{s}), l$ is the half of the slab thickness (m)

The effective moisture diffusivity ( $\mathrm{D}_{\text {eff }}$ ) was calculated from the slope of plot of $\ln \mathrm{MR}$ against drying time (t) according to Doymas, (2004) and is represented in Equation 4

$$
D_{e f f}=k \frac{4 l^{2}}{t}
$$

Where $k$ is the slope.

\section{(d) Determination of Activation Energy}

The Arhenius Equation describes the relationship between moisture diffusion and temperature of drying. The relationship is given in Equation 5.

$$
\begin{aligned}
& D_{e f f}=D_{0} \exp \frac{-E_{a}}{R T} \\
& E_{a}=-\ln \left(\frac{D_{e f f}}{D_{0}}\right) x R T
\end{aligned}
$$

Where $\mathrm{D}_{0}$ is the pre-exponential factor of the Arrhenius equation in $\mathrm{m}^{2} / \mathrm{s}, \mathrm{E}_{\mathrm{a}}$ is the activation energy in $\mathrm{kJ} / \mathrm{mol}, \mathrm{R}$ is the universal gas constant in $\mathrm{kJ} / \mathrm{mol} \mathrm{K}$ and $\mathrm{T}$ is the absolute air temperature in $\mathrm{K}$. 
The activation energy was calculated by plotting the natural logarithm of $D_{\text {eff }}$ against the inverse of the absolute temperature.

\section{(e) Statistical Analysis}

The drying model constants were estimated using a non-linear regression analysis. The analysis was performed using Statistical Package for Social Sciences (SPSS 16.0 versions) software. The reliability of the models was verified using some statistical criteria; coefficient of determination

$\left(\mathrm{R}^{2}\right)$, reduced chi-square $\left(\chi^{2}\right)$, root mean square error (RMSE) and mean bias error (MBE). A good fit is said to occur between experimental and predicted values of a model when $\mathrm{R}^{2}$ is high and $\chi^{2}$, RMSE and MBE are low (Ajala et al., 2012a). The comparison criteria method can be determined as follows:

$$
\begin{gathered}
\chi^{2}=\frac{\sum_{i-1}^{n}\left(M R_{(\exp i)}-M R_{(\text {pred }, i)}\right)^{2}}{N-z} \\
\mathrm{MBE}=\frac{1}{N} \sum_{i=1}^{n}\left(M R_{(\text {pred }, i)}-M R_{(\exp j)}\right) \\
\mathrm{RMSE}=\left[\frac{1}{N} \sum_{i=1}^{n}\left(M R_{(\text {pred }, i)}-M R_{(\exp i)}\right)^{2}\right]^{1 / 2}
\end{gathered}
$$

\section{Results and Discussion}

\section{Effect of drying on moisture content of oyster mushroom}

The nature of reduction in moisture content and moisture ratio of the mushroom as drying progressed is as shown Figures 1and 2. It took about 11, 9 and 7 hours for oyster mushroom samples dried in the sun, solar and tunnel, respectively, to dry. All the drying modes exhibited a single falling rate which is common to all agricultural products (Thuwapanichayanan et al., 2008). Temperatures had a significant effect on drying time because the higher the temperature, the lower the time. For example, at temperature of $50^{\circ} \mathrm{C}$, drying took 17 hours in the tunnel drying whereas in the solar $\left(40^{\circ} \mathrm{C}\right)$ and sun $\left(30^{\circ} \mathrm{C}\right)$ drying, it took 19 and 22 hours, respectively as shown in Figures 1 and 2. The reason for this, according to Machhour et al. (2012), is that at increased temperature, water molecules become activated to higher energy levels causing them to become less stable and to break away from the water binding sites of the food material. Observation on such assertion also has been earlier reported by authors such as Ajala et al., (2020) and Giannini et al., (2010)

\section{Statistical results and Constants of the Models}

Statistical tools such as coefficient of determination $\left(\mathrm{R}^{2}\right)$, reduced chi-square $\left(\chi^{2}\right)$, Mean Bias Error (MBE) and Root Mean Square Error (RMSE) were used to test the goodness of fit for the models in consideration. The results of these statistical values are as shown in Table 2. The range of results of $\mathrm{R}^{2}$ for Henderson and Pabis , Logarithms, Newton, Page, Two-term and Midilli-Kucuk models is 0.933-0.953, 0.973-0.987, 0.933-0.953, 0.939-0.956, 0.973-0.988 and 0.977-0.984, respectively. Also, the range of results for values of $\chi^{2}$ is $0.028-0.035,2.3 \mathrm{E}-06-1.4 \mathrm{E}-05,0.026-0.034,0.001-$ 0.044, 7.5E-07-1.5E-05 and 2.3E-4-0.001, respectively, for Henderson and Pabis, Logarithms, 
LAUTECH Journal of Civil and Environmental Studies

Volume 6, Issue 1; March 2021

Newton, Page, Two-term and Midilli-Kucuk models. Furthermore, the range of values of MBE for Henderson and Pabis , Logarithms, Newton, Page, Two-term and Midilli-Kucuk models were 0.0340.039, -7.6E-4-(-3.1E-4), 0.034-0.039, 0.006-0.021, -7.6E-4-1.7E-4 and 0.003-0.008, respectively, while the range of results for values of RMSE were $0.160-0.179,1.4 \mathrm{E}-3-0.003,0.016-0.179,0.029$ 0.201, 7.8E-4-0.004 and 0.014-0.040, respectively, for Henderson and Pabis , Logarithms, Newton, Page, Two-term and Midilli-Kucuk models.

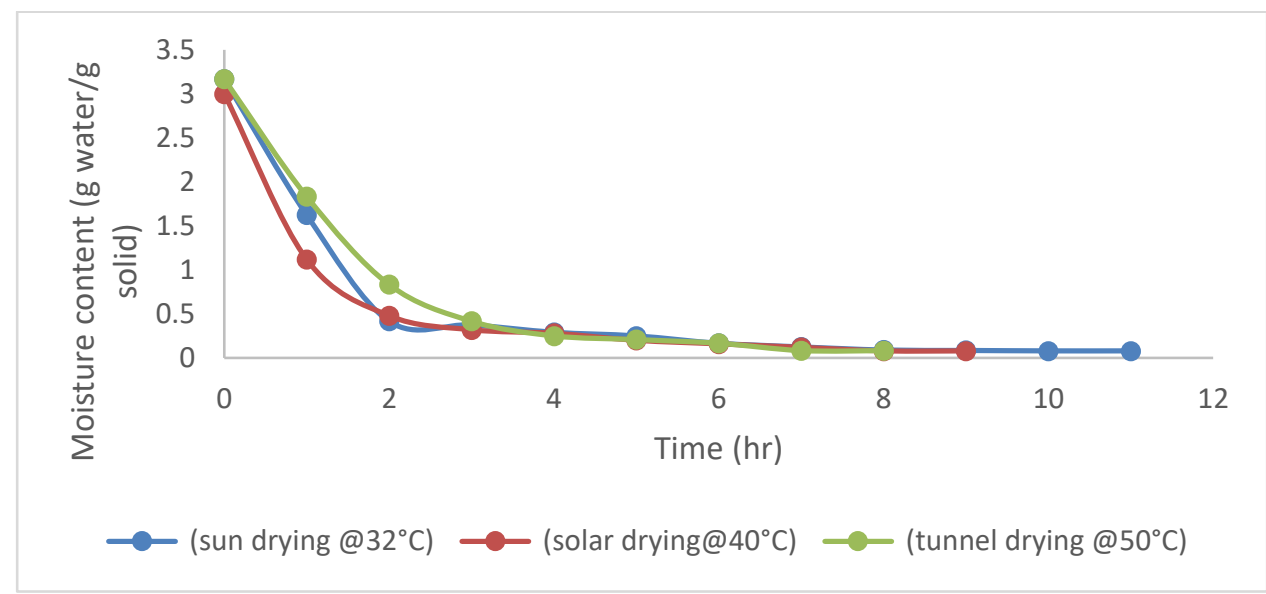

Figure 1. Graph showing moisture content against time

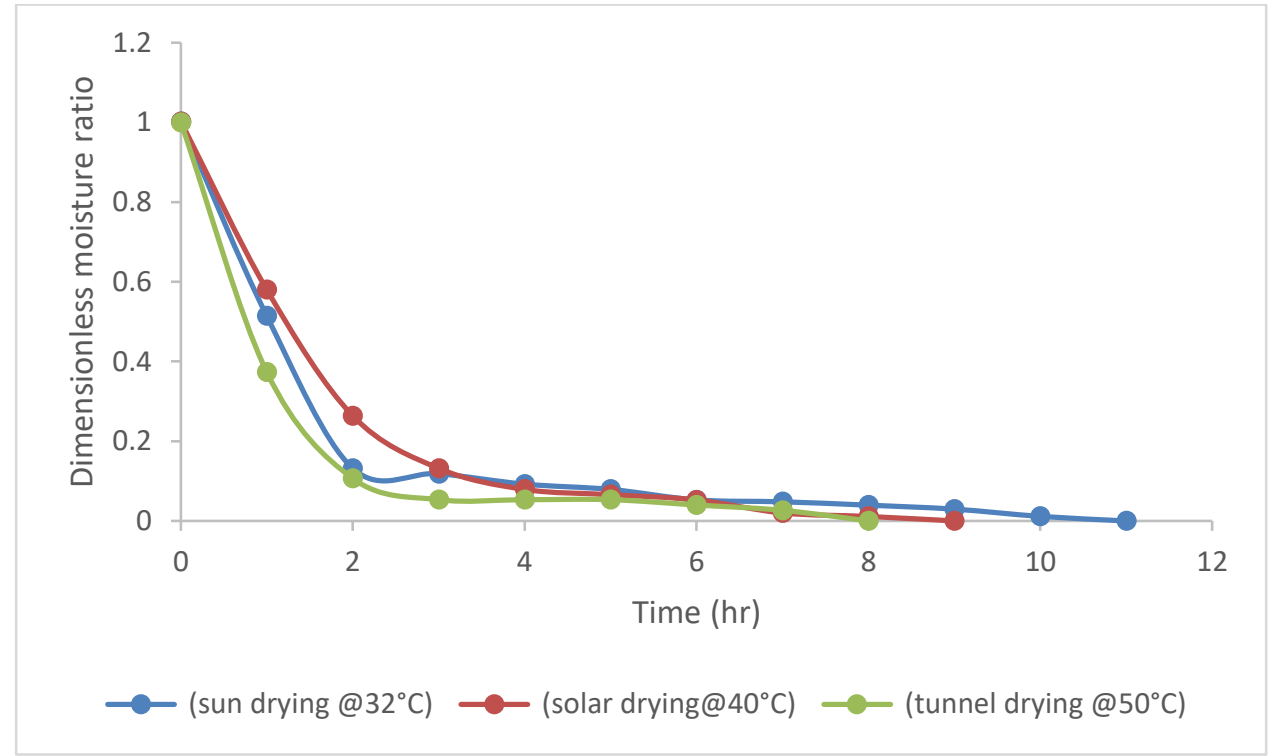

Figure 2. Graph showing moisture ratio against time

Since choosing the best model depends on the best goodness of fit which implies the highest value $\mathrm{R}^{2}$ and lowest values of other criteria as earlier asserted by Ajala et al., (2019), this suggests that the Two-Term model had the best fit in the tunnel drying for oyster mushroom drying. 
Table 2. Values for model constants

\begin{tabular}{|c|c|c|c|c|c|}
\hline Models & Drying mode & $\mathrm{R}^{2}$ & $\chi^{2}$ & MBE & RMSE \\
\hline Henderson and & Sun & 0.933 & 0.035 & 0.039 & 0.179 \\
\hline \multirow[t]{2}{*}{ Pabis } & Solar & 0.935 & 0.034 & 0.038 & 0.175 \\
\hline & Tunnel dryer & 0.953 & 0.028 & 0.034 & 0.160 \\
\hline \multirow[t]{3}{*}{ Logarithms } & Sun & 0.977 & $2.4 \mathrm{E}-06$ & $-3.2 \mathrm{E}-4$ & $1.5 \mathrm{E}-3$ \\
\hline & Solar & 0.973 & $1.4 \mathrm{E}-05$ & $-7.6 \mathrm{E}-4$ & 0.003 \\
\hline & Tunnel dryer & 0.987 & $2.3 \mathrm{E}-06$ & $-3.1 E-4$ & $1.4 \mathrm{E}-3$ \\
\hline \multirow[t]{3}{*}{ Newton } & Sun & 0.933 & 0.034 & 0.039 & 0.179 \\
\hline & Solar & 0.935 & 0.033 & 0.038 & 0.177 \\
\hline & Tunnel dryer & 0.953 & 0.026 & 0.034 & 0.160 \\
\hline \multirow[t]{3}{*}{ Page } & Sun & 0.943 & 0.001 & 0.006 & 0.029 \\
\hline & Solar & 0.939 & 0.044 & 0.044 & 0.201 \\
\hline & Tunnel dryer & 0.956 & 0.010 & 0.021 & 0.096 \\
\hline \multirow[t]{3}{*}{ Two term } & Sun & 0.977 & $2.6 \mathrm{E}-06$ & $-3.2 \mathrm{E}-4$ & 0.001 \\
\hline & Solar & 0.973 & $1.5 \mathrm{E}-05$ & $-7.6 \mathrm{E}-4$ & 0.004 \\
\hline & Tunnel dryer & 0.988 & $7.5 \mathrm{E}-07$ & $1.7 \mathrm{E}-4$ & $7.8 \mathrm{E}-4$ \\
\hline \multirow[t]{3}{*}{ Midilli-Kucuk } & Sun & 0.984 & $2.3 \mathrm{E}-4$ & 0.003 & 0.014 \\
\hline & Solar & 0.977 & $4.1 \mathrm{E}-4$ & 0.004 & 0.018 \\
\hline & Tunnel dryer & 0.982 & 0.001 & 0.008 & 0.040 \\
\hline
\end{tabular}

The values of constants in various models are as shown in Table 3. The range of values of $\mathrm{a}_{1}$ and $\mathrm{k}_{1}$ were 0.999-1.014 and 0.599-1.000 respectively, for Henderson and Pabis. However, the range of values for $\mathrm{a}_{2}, \mathrm{c}_{2}$ and $\mathrm{k}_{2}$ is $0.956-0.972,0.049-0.050$ and $0.709-1.173$, respectively, for the Logarithms model while the range of values of $\mathrm{k}_{3}$ in the Newton model are 0.593-1.000. Also, the range of values of $\mathrm{n}_{4}$ and $\mathrm{k}_{4}$ are $0.383-1.145$ and -1.331-(-0.682) for the Page model. The range of values of constant $\mathrm{a}_{5}, \mathrm{~b}_{5}, \mathrm{j}$ and $\mathrm{k}_{5}$ are $0.952-0.975,0.046-0.063,-1.185-(-0.728)$ and $-0.007-0.005$, respectively, for the Two-term model while the Midilli-Kucuk model which has constants $\mathrm{a}_{6}, \mathrm{~b}_{6}, \mathrm{n}$ and $\mathrm{k}_{6}$ has the range of values of 1.002-1.008, 0.00-0.003, 0.545-1.018 and 0.617-1.123, respectively.

\section{Effective Diffusivity}

The values of moisture diffusivities of oyster mushroom using different modes of drying are as presented in Table 4. Samples dried in sun with an average temperature of $32{ }^{\circ} \mathrm{C}$ had the lowest value of $1.19 \times 10^{-11} \mathrm{~m}^{2} / \mathrm{s}$ followed by sample dried in a solar dryer with an average temperature of $40^{\circ} \mathrm{C}$ had a value of $1.21 \times 10^{-11} \mathrm{~m}^{2} / \mathrm{s}$ while the highest value was $1.59 \times 10^{-11} \mathrm{~m}^{2} / \mathrm{s}$ which occurred in tunnel dryer at $50^{\circ} \mathrm{C}$. From these values, temperature did play a significant role because increase in drying temperature increased the moisture diffusivity. The reason for this, according to Machhour et al. (2012), is that at increased temperature, water molecules become activated to higher energy levels causing them to become less stable and to break away from the water binding sites of the food material. This observation is in line with other authors such as Ajala et al. (2018), Ajala and Ajala (2014) and Doymaz (2007). 
LAUTECH Journal of Civil and Environmental Studies

Volume 6, Issue 1; March 2021

Table 3. Values of statistical parameters

\begin{tabular}{llllll}
\hline Models & Drying mode & Constants & & & \\
\hline \multirow{3}{*}{ Henderson and Pabis } & Sun & $\mathrm{a}_{1}$ & & & $\mathrm{k}_{1}$ \\
& Solar & 0.999 & & & 1.000 \\
& Tunnel dryer & 1.014 & & & 0.808 \\
& & 1.004 & & & 0.599 \\
Logarithms & Sun & 0.956 & & $\mathrm{c}_{2}$ & $\mathrm{k}_{2}$ \\
& Solar & 0.972 & & 0.049 & 1.173 \\
& Tunnel dryer & 0.968 & & 0.049 & 0.934 \\
& & & 0.050 & 0.709 \\
Newton & Sun & & & & $\mathrm{k}_{3}$ \\
& Solar & & & & 1.000 \\
& Tunnel dryer & & & & 0.798 \\
& & & $\mathrm{n}_{4}$ & & 0.597 \\
Page & Sun & & 0.383 & & -1.331 \\
& Solar & & 1.145 & & -0.682 \\
Two-term & Tunnel dryer & & 0.741 & & -0.709 \\
& & $\mathrm{a}_{5}$ & $\mathrm{~b}_{5}$ & $\mathrm{~J}$ & $\mathrm{k}_{5}$ \\
& Sun & 0.952 & 0.053 & -1.185 & -0.007 \\
& Solar & 0.975 & 0.046 & -0.928 & 0.005 \\
& Tunnel dryer & 0.956 & 0.063 & -0.728 & -0.019 \\
& & $\mathrm{a}_{6}$ & $\mathrm{~b}_{6}$ & $\mathrm{~N}$ & $\mathrm{k}_{6}$ \\
& Sun & 1.002 & 0.001 & 0.545 & 1.123 \\
Midilli-Kucuk & Solar & 1.008 & 0.003 & 0.988 & 0.774 \\
& Tunnel dryer & 1.008 & 0.003 & 1.018 & 0.617 \\
\hline
\end{tabular}

Table 4. Effective moisture diffusivities for oyster mushroom

\begin{tabular}{lc}
\hline Drying mode & Effective moisture diffusivity $\left(\mathrm{m}^{2} / \mathrm{s}\right)\left(\mathrm{D}_{\mathrm{eff}} \mathrm{X} 10^{-11}\right)$ \\
\hline Sun drying $\left(32^{\circ} \mathrm{C}\right)$ & 1.19 \\
Solar $\left(40{ }^{\circ} \mathrm{C}\right)$ & 1.21 \\
Tunnel dryer $\left(50^{\circ} \mathrm{C}\right)$ & 1.59 \\
\hline
\end{tabular}

\section{Activation energy}

The derivation energy of activation of the drying process of oyster mushroom is done by the relationship between the natural logarithm of moisture diffusivity $(\operatorname{lnD})$ and the temperature inverse as shown in Figure 3. The activation energy was found to be $19.825 \mathrm{~kJ} / \mathrm{mol}$. This is the minimum energy that would be needed to effect the drying process of oyster mushrooms. The value is lesser than the values of cocoa $(28.11 \mathrm{~kJ} / \mathrm{mol})$ reported by Hii et al., (2009). 


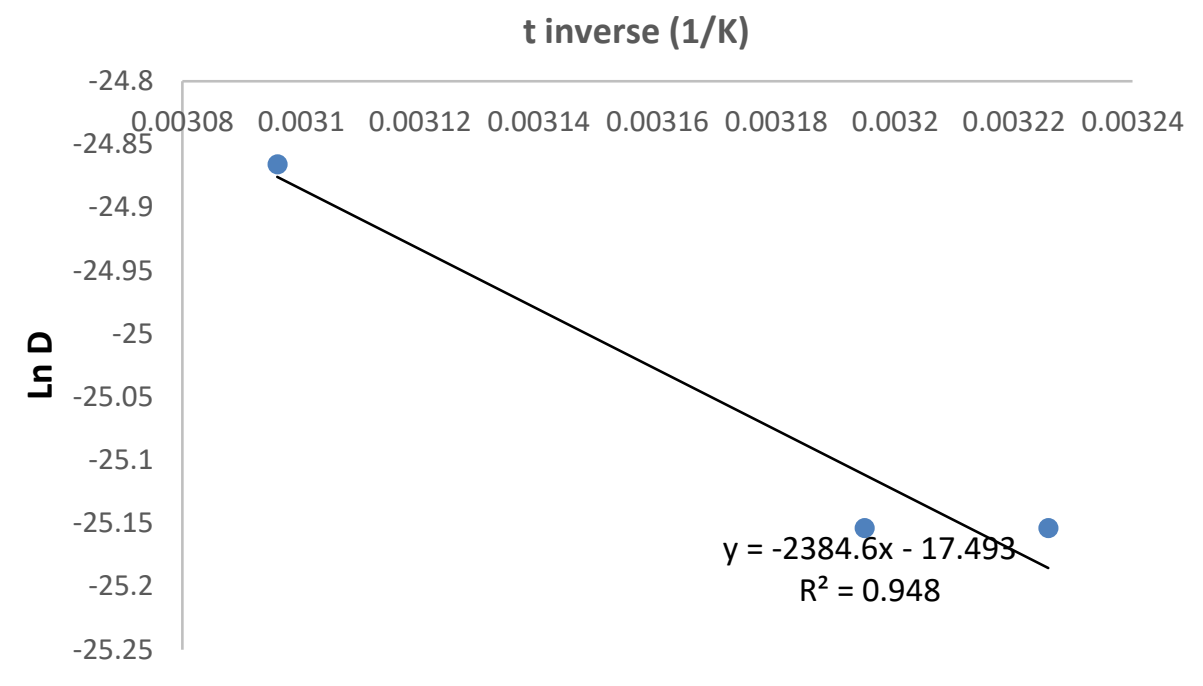

Figure 3. Plot of $\ln \mathrm{D}$ versus Temperature Inverse

\section{Conclusion}

From the study, Fick's second law of diffusion for the thin-layer drying was used to model drying behaviours of oyster mushroom. It is concluded that

i. Drying characteristic of the samples was in the single falling rate pattern

ii. The higher the temperature of drying, the shorter the drying time

iii. Two Term model best represented the drying characteristics of oyster mushroom in tunnel drying compared to other models.

iv. Effective moisture diffusion during the experiment increased with increase in temperature.

v. The activation energy of the drying process was $19.825 \mathrm{~kJ} / \mathrm{mol}$.

\section{Nomenclature}

$\begin{array}{ll}a & \text { Drying constant in the model } \\ b & \text { Drying constant in the model } \\ c & \text { Drying constant in the model } \\ k & \text { Drying constant in the model } \\ l & \text { half of the thickness of the sample }(m) \\ M_{0} & \text { initial moisture content of the sample }(g \text { water } / g \text { solid }) \\ M_{i} & \text { instantaneous moisture content of the sample }(g \text { water } / g \text { solid }) \\ M_{e} & \text { equilibrium moisture content of the sample }(g \text { water } / g \text { solid }) \\ M B E & \text { mean bias error } \\ M R & \text { moisture ratio } \\ M R_{\text {exp }} & \text { experimental moisture ratio } \\ M R_{p r e} & \text { predicted moisture ratio } \\ n & \text { Drying constant in the model } \\ N & \text { number of observation } \\ R M S E & \text { root mean square error } \\ R^{2} & \text { coefficient of determination } \\ t & \text { drying time (hr) } \\ \chi^{2} & \text { reduced chi-square } \\ z & \text { number of constant in the models }\end{array}$


LAUTECH Journal of Civil and Environmental Studies

Volume 6, Issue 1; March 2021

\section{References}

Ajala, A.S., Aboiye, A.O, Popoola, J.O. and Adeyanju, J.A. (2012a). Drying characteristics and mathematical modelling of cassava chips. Chemical and Process Engineering Research, 4: 1-9

Ajala A.S., Ajala F.A and Tunde Akintunde, T.Y. (2012b). Study on drying kinetics of fermented corn grains. Food Science and Quality Management, 5:10-18

Ajala, A.S. and Ajala, F.A. (2014). A study on drying kinetics of shrimps. International Journal of Innovation and Applied Studies, 9(4): 1778-1785

Ajala, A.S. and Taiwo, T.F. (2018). Study on supplementation of 'ogi' with oyster mushroom flour (Pleurotus ostreatus). Journal of Nutritional Health and Food Engineering, 8(3):287-291

Ajala, A. S., Ngoddy, P. O. and Olajide, J. O. (2018). Design and construction of a tunnel dryer for food crops drying. International Multidisciplinary Research Journal, 8:1-7

Ajala A. S., Olaniyan S. A., Fasonyin O. T. and Adeoye A. O. (2019). Production and optimization of citric acids from cassava peels using Aspergillus Niger. World Journal of Engineering Research and Technology, 5(2): 187-199

Ajala, A. S., Ngoddy, P. O. and Olajide, J. O. (2020). Sorption isotherms and their fitted equations for dried chips of cassava roots (Manihot Esculenta Crantz; Tme-7 variety) and the resulting isosteric heats of sorption, Food Research, 4(3):703-711

Caglarirmak N. (2007). The Nutrients of Exotic Mushrooms (Lentinula edides and Pleurotus species) and Estimated Approach to the Volatile compounds. Food Chemistry 105(3):11881194.

Celik Y and K Peker (2009). Benefit/cost analysis of mushroom production for diversification of income in developing countries. Bulgarian Journal of Agricultural Science 15: $228-237$

Doymaz, I. 2004. Convective air drying characteristics of thin layer carrots. Journal of Food Engineering, 61(3): 359-364.

Doymaz, I. 2007. Air drying characteristics of tomatoes. Journal of Food Engineering, 78:12911297

Eswaran A. and Ramabradan R. (2000). Studies on some physicological, cultural, and post-harvest aspects of oyster mushroom, (Plerotus ostreatus). Tropical Agricultural Restoration, 12:360374.

Giannini, P.A., Sandra, A.F. and João, B.L. (2010). Drying and rehydration of oyster mushroom, Brazilian Archives of Biology and Technology, 53 (4):1-7

Gebretsadkan G. (2015). Assessment of urban agriculture in Addis Ababa: The case of mushroom cultivation. MSc Thesis. Addis Ababa University.

Goyal, R.K., Kingsley, A.R.P., Manikantan, M.R., and Ilyas, S.M. 2007. Mathematical modeling of thin-layer drying kinetics of plum in a tunnel dryer. Journal of Food Engineering, 79(1): 176-180

Hii, C.L., Law, C.L. and Cloke, M. (2009). Modeling using a new thin layer drying model and product quality of cocoa. Journal of Food Engineering, 90: 191-198

Hodge, B. K. \& Taylor, R. P. (1999). Analysis and Design of Energy Systems, 3rd Ed., Prentice Hall Inc., New Jersey,

Jonathan S. G. and Esho E.O. (2010). Fungi and aflatoxin detection in two oyster mushrooms Pleurotus ostreatus and Pleurotus pulmonarius from Nigeria. Electronic Journal of Environmental, Agricultural and Food Chemistry (EJEAFche), 9(11):1722-1730. 
Jonathan S.G., Okon, C.B., Oyelakin A.O. and Oluranti O.O. (2012). Nutritional values of oyster mushroom (Pleurotus ostreatus) (Jacq. Fr.) Kumm. cultivated on different agricultural wastes. Nature and Science, 10 (9):186-189

Karathanos, V.T. \& Belessiotis, V. G. (1999). Application of a thin layer equation to drying data of fresh and semidried fruits. Journal of Agricultural Engineering Research, 74, 335-361,

Kingly, R.P., Goyal, R.K., Manikantan, M.R. and Ilyas, S.M. (2007). Effect of pretreatment and drying air temperature on drying behaviour of peach slice. International Journal of Food Science and Technology, 4:65-69

Kurtzman R.H. (2005). Mushrooms: Sources of Modern Western Medicines. Micologia Aplicada International 17(2):21-33

Lukasse, L.J.S.; Polderdijk, J.J. (2003), Predictive modelling of post-harvest quality evolution in perishables, applied to mushrooms. Journal of Food Engineering, 59: 191-198

Machhour, H., Idlimam, A., Mahrouz, M., El Hadrami, I. and Kouhila, M. (2012). Sorption isotherms and thermodynamic properties of peppermint tea (Mentha-piperita) after thermal and biochemical treatment. Journal of Materials and Environmental Science, 3(2), 232-247

Maray, A.R.M., Mostafa, M.K., El-Fakhrany, A.E.-D.M.A. (2017). Effect of pre-treatments and drying methods on physico-chemical, sensory characteristics and nutritional value of oyster mushroom. Journal of Food Processing and Preservation, 42, e13352

Manzi P., Gambelli L., Marconi S., Vivanti V., Pizzoferrato L. (1999). Nutrients in Edible Mushrooms: An Inter-Species Comparative Study. Food Chemistry, 65(4): 477-482.

Midilli, A., Kucuk, H. and Yapar, Z. (2002). A new model for single-layer drying. Drying Technology, 20 (7), 1503-1513.

Sergey, P., Lyudmila, T., Wolf-Dieter, G., Igor, R., Svetlana, A., Marina, S. and Vladimir, K. (2020). Effects of various drying methods on some physico-chemical properties and the antioxidant profile and ACE inhibition activity of oyster mushrooms (Pleurotus ostreatus). Foods 9, 160: 1-26

Thuwapanichayanan, R., Prachayawarakorn, S. and Soponronnarit, S. (2008). Drying characteristics and quality of banana foam mat. Journal of Food Engineering, 86, 573-583.

Togrul I.T. and Pehlivan D., 2003. Modelling of drying kinetics of single apricot. Journal of Food Engineering, 58, 23-32.

Zadrazil, F. and Kurtzman, R. H. (1981), The biology of Pleurotus cultivation in the tropics. In: Chang, S. T., Quimio, T. H. Tropical Mushrooms. The Chinese Univ. Press, Shatin, Hong Kong, pp. 493.

Zhang Y, Geng W, Shen Y, Wang Y, Dai YC (2014). Edible mushroom cultivation for food security and rural development in China: bio-innovation, technology dissemination and marketing. Sustainability, 6: 2961-2973. 